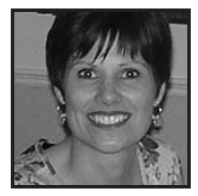

\title{
The Situation of Parents in the Curricular Commonplaces: A Place of Equal Rank?
}

\author{
Debbie Pushor, University of Saskatchewan
}

\section{ABSTRACT (Press Here for Sound)}

Schwab (1973) argued that four commonplaces of equal rank must be taken into account in curriculum making: students, teachers, subject matter and milieus. While he insisted that none of the commonplaces can be omitted without a vital loss, attention to milieus, particularly in relation to parents and families (rather than schools or classrooms), is largely being omitted in teacher education curriculum. This article explores how a teacher education curriculum attending to the positioning of parents helped interrupt one teacher's story of parents. The article challenges us to consider who is rendered in/visible, who is in/validated, who finds schooling an educative process - and who is/does not-in the dominant plotline of parents as outsiders to curriculum.

\footnotetext{
$S$ chwab (1973), a well-known curriculum theorist, argued that curriculum must be comprised of four commonplaces of equal rank: the learners, the teachers, the subject matter, and the milieus. Knowledge of the learners, for Schwab, included both a general knowledge of the age group and an intimate knowledge "achieved by direct involvement with them" (p. 502). Knowledge of the teachers included knowledge of their backgrounds and their personalities, what they know and what they are ready to learn. Knowledge of the subject matter included knowledge of the scholarly materials of the discipline. Knowledge of milieus included attention to the school and classroom, the family, the community, and "particular groupings of religious, class, or ethnic genus" (p. 503). It attended to relations between and among children, children and adults, and the various subgroups and communities.
} 
Schwab asserted that "[n]one of [the commonplaces] can be omitted without omitting a vital factor in educational thought and value" (p. 509). He spoke of the relations between the commonplaces as being one of "coordination, not superordinationsubordination" (p. 509).

If I were to take a quick survey of the current curriculum field, would I see attention being paid to all four curricular commonplaces? Would I see a foregrounding of the commonplaces as equal in rank? In regard to learners, a review of courses offered in representative Canadian teacher education programs makes apparent to me there is a continued shift of attention away from teaching toward that of learning. I see a common focus on aspects of learning such as assessment for learning, student reflection and metacognition, the interplay of gender in subject matter learning, and processes of student inquiry. In regard to teachers, my search of "teacher knowledge" and "teacher identity" in our library database produces a large body of literature. ${ }^{1}$ In schools and school divisions, I see professional learning communities abounding, underpinned by work such as Craig's (2003) conceptualization of knowledge communities. In regard to subject matter, I observe the continued revision of curriculum documents across Canadian provinces and territories. I hear subject matter specialists each speak of the literacies of their discipline-ecological literacy, mathematical literacy, the range of literacies within the field of technology. Within the subject matter areas, I witness a renewed emphasis on constructivist pedagogy, of inviting students to learn how to learn rather than what to learn. And what about milieus? Have there been any shifts in attention in this commonplace? Do I see recognition of the family and community as places of learning for children? Do I see what parents know about children, and about teaching and learning, being acknowledged and used in classrooms alongside teacher knowledge? Do I see parent knowledge being used to inform decisions on school landscapes about curricular policy and programming?

There is a large and growing body of literature on parents and schooling which speaks to the positive impact parent engagement has on their children's academic achievement and other educational outcomes (Henderson \& Mapp, 2002; Hoover-Dempsey et al., 2005; Jeynes, 2005; Redding et al., 2004). In the face of this field of research, a lack of attention to the curricular commonplace of milieus, particularly in regard to parents and families, continues. In a search of 10 prominent universities in Canada, no undergraduate teacher education courses were identified which offer a curriculum focusing on parents. At the graduate level, two teacher education courses were identified: one at the University of Alberta, ECE: Home/School/ Community Relations, last offered in Summer Session 2008, and one at the University of Saskatchewan, Parents and Education: Contemporary Developments and Issues, last 
offered in Spring Session 2007. ${ }^{2}$ While I am aware that the topic of parents is an element in some courses, particularly in educational administration courses in relation to governance and roles and responsibilities as defined by the School Act, or in educational foundations courses which explore cultural and historical constructions of childhood or the family, ${ }^{3}$ a foregrounding of beliefs and practices around the engagement of parents in their children's schooling is not a focus in courses offered by curriculum studies departments.

Recently, in a lunch time conversation, a group of teacher educators were conversing about the experiences of their students in field experience placements. As stories were shared, stories of parents became a part of their telling. I was struck by the term "helicopter parents," apparently a term used by some teachers in a school to describe parents who are perceived to ask too many questions, to visit the school too frequently, and who want to be too big a part of the daily life which unfolds there. Not long afterward, I was participating in a meeting with teachers and student teachers in which we were determining dates and activities in which the students could be out and engaged in the school. Again I was struck when a teacher insisted that the student teachers not be present during parent-teacher conferences. My sense was that she felt it was too anxious and exhausting a time for teachers to have any added considerations. I believe we see reflected, in both of these instances, a dominant plotline common in education, a plotline which positions parents as outsiders to the school landscape, as individuals who are perhaps demanding, interfering, needy-and perhaps, even, people of whom to be wary. Without consciously designed curriculum, at preservice, inservice and graduate levels of education, how do we interrupt this dominant plotline to create new stories of parents, stories in which parents are positioned alongside educators in relational and equitable ways? How do we interrupt this dominant plotline so that we do not continue to omit a "vital factor" (Schwab, 1973, p. 509) in the schooling of children?

\section{Kelly's Story: Living the Dominant Plotline}

In this story, Kelly Lacey, a practicing teacher, moves backward in time to her early days of teaching to tell a story of her lived experience with one family. She makes visible the assumptions and beliefs she held at that time regarding parents and their position in relation to their children's school landscapes. Kelly's story, in its detail and particularity, invites us to learn-and to "unlearn" (Williams, in Loomba, 1998, p. 66)—alongside her. 
I am reminded of an experience I had with a parent during the early years of my teaching career. I was teaching a grade 3 class at a perimeter city school in which Beverley (a pseudonym) was a student. I remember Beverley's quick smile and clever, intuitive ways, her surprising distance from the other students and her daily visits with me after school where we would talk about books she was reading and the journal she often chose to write in during the evening. Like many students that year, Beverley came dressed in clothes that were dated and old, but clean.

In November I expected to meet her parents at the scheduled interview yet, to my surprise, no one showed up. While poor parental attendance for parentteacher interviews was quite common for that school, I anticipated that someone would arrive for Beverley since she was doing well in school. In retrospect, I made several assumptions without ever meeting or communicating in any way with her parents.

Throughout the year, bits of information began to change my understanding of Beverley's home life. I was to learn that her father was an alcoholic who was unemployed, angry, and explosive; her mother had left them during the middle of the night while the kids were very small; Beverley and her older brother were responsible for a significant number of daily chores that included washing their clothes and making their lunches; Beverley spent a lot of time in her bedroom with the door shut reading and writing in her journal; and, Austin (also a pseudonym), Beverley's older brother, was the troubled boy I often heard other teachers talking about. Regrettably, I never once spoke with Beverley's father that year.

The following year, I was given a grade 7/8 combined classroom. The students were remarkably diverse and confrontational. One of the children within the class was Beverley's older brother, Austin. Austin would fight with kids, swear in class, and challenge me, other teachers, and administrators in seemingly any manner he could. He was violently angry, and during the year he was suspended many times. I hoped desperately that with time and patience he would come to trust me and that his behavior would improve. As I search my photo album for a picture of Austin, I am struck by the fact that while I have several class pictures from that year, I have no pictures of him. It speaks to me of his distance from school, from me, and from his peers.

Quite soon into the school year, I called Austin's father at home to speak to him about his son's rude and violent behavior. By this time, I had been warned by my 
colleagues of the volatile nature of this single parent. While not necessarily expecting appreciation over the phone call home, I did expect he would hear me and offer some support in dealing with his child. Instead, his reaction was awkward, angry silence.

Our strained communication became increasingly hostile as the year went on. Austin's father blamed me for setting his son off or for picking on him. I recall my incredulous reaction that he felt I could be to blame for his son's behavior. Certainly, as Austin grew, so did his anger. I remember the principal being present during my scheduled meetings with his father and how my interactions with his father continued to deteriorate to the point where I was fearful for my personal safety. Years later, I am struck by the lasting personal impact this negative relationship has had on me. I now also wonder about the impact it had on Beverley, Austin, and their father. (Lacey, 2007, pp. 90-93)

\section{Interrupting the Dominant Plotline}

During her master's program, Kelly took a course entitled Parents and Education: Contemporary Developments and Issues. The course centered on four themes: challenging assumptions, parents in context, parents in educational policy, and parents and curriculum (Pushor \& Stelmach, 2007). It was during this course that Kelly pulled forward this story, a story that had stayed with her, a story that continued to have an effect on her years later. In relation with her instructors and her classmates, and in "conversation" with course readings, Kelly was able to tell her story-and to retell it, and retell it, and retell it-as she came to know and understand it differently.

I recently paused to reconsider the dynamics of the relationship I had with that father through a different lens. I realize now I made many assumptions about who he was, his parental skills, his lack of involvement within the school, his anger, and his family. From my first interaction with him, I was unintentionally negative and judgmental. Upon reflection, why would I have expected the interaction between this father and me to have been any different? We had no relationship. Why would he trust me when all I did was judge his child, his parenting, and his life?

I realize now I missed an incredible opportunity by failing to make contact with Beverley's father during the time I taught her. That year could have been a gift, one where a positive relationship between school and home could have been nurtured, and one that allowed Beverley and her father opportunities to 
celebrate success. I wonder now, how many times did Beverley or her father receive positive phone calls or messages from the school? I did not bother to reach out because I perceived all was well at school for Beverley, and yet it would have been so simple and so potentially powerful in changing our relationship.

The next year, while I taught Austin, I never once called home with a positive statement. Moreover, while I remember many details of this family, I cannot recall the name of the father. That in itself speaks volumes. I never valued him or his opinions, or considered for a moment that he could teach me about his children. What a loss. I was the knower, the professional. I was the empowered critic. The message I gave, the one he clearly received, was I knew best. He had no voice. It is no wonder he spoke in anger and that I in turn felt rendered voiceless by his anger, when all of our conversations were silently encircled by judgment. (Lacey, 2007, pp. 93-95)

Kelly's telling and retelling of her story challenges us to consider what opportunities are missed, and what harm may be done, when educators continue to live out the dominant plotline in their stories of parents. Her story challenges us to consider who is rendered visible, who is validated, who finds schooling an educative process (Dewey, 1938) —and who is/does not.

\section{Unpacking Kelly's Story}

In Kelly's story, we see her implicit beliefs about the position of educators being lived out. When she travels backward in time to her early years as a beginning teacher, she remembers herself as someone who believed she was a knower, a holder of professional knowledge, someone who knew best. In speaking of Austin's father she writes, "I never valued him or his opinions, or considered for a moment that he could teach me about his children." She expected that when she called him at home, he would hear her and offer her support. It was her knowledge of teaching and learning that she saw as central.

When Kelly recalls her concern for Austin at that point in time, she recalls her concern as being related to the classroom and school setting. "Austin would fight with kids, swear in class, and challenge me, other teachers, and administrators in seemingly any manner he could." She does not speak about wondering if he displayed this anger at home as well, or out in the community. She does not speak about wondering about or knowing what his relationship with his sister or his father was 
like. She does not situate herself as knowing how Austin spent his time outside of school, other than to mention the chores he was responsible for. She expresses no wonders about links between his anger and the large responsibilities he seemed to carry in his life. Her school goals-for Austin to be respectful and to get along with others-seem to be the goals which she saw as taking priority. The place of school was the center of her concern.

In looking backward, Kelly tells us, first, of her warm relationship with Beverley and then, later, of her troubled relationship with Austin. While the potential for a relationship with the children's father began with Beverley, Kelly did not meet him until she was seeking support from him for her interactions with Austin. At the time, she saw her responsibility as being solely to the children. A relationship with the father was not deemed necessary when Beverley was her student because Beverley was compliant and doing well in school. It only became necessary to her when she wanted the father's support in responding to Austin's behavior.

Kelly's story awakens us more deeply to what is problematic when we continue to live out beliefs such as these according to the dominant plotline. What opportunities were missed? As she moves forward in time, with more years of teaching experience, now as a mother of three sons, and as a graduate student engaged in coursework on parents and education, Kelly sees the "incredible opportunity" she missed in not building a relationship with Beverley's and Austin's father. "That year could have been a gift ..."-time to nurture a positive relationship, time to celebrate strengths and successes, time to learn from one another. She recognizes now the father had knowledge to share with her about his family and his children, knowledge she could have learned from, knowledge that would have enriched her interactions with all of them and their experiences with school.

What harm may have been done? In her story Kelly says, "I realize now I made many assumptions about who he was, his parental skills, his lack of involvement within the school, his anger, and his family. From my first interaction with him, I was unintentionally negative and judgmental." She sees how, in judging him as deficit or lesser, she gave up the opportunity to build trust and a relationship with this father. Their lack of relationship led to each one blaming the other for the difficulties Austin was experiencing in school. "Austin's father blamed me for setting his son off or for picking on him. I recall my incredulous reaction that he felt I could be to blame for his son's behavior." With this statement of incredulity, Kelly implies that the fault lies elsewhere-perhaps in the home? - perhaps with the father's drinking or his parenting skills? With the need for someone to be at fault, for there to be someone who 
is right and someone who is wrong, their interactions deteriorated to the point where the principal needed to be present when they met. Kelly continues to feel the lasting hurt of their negative interactions. She wonders now how the father and his children may have been hurt by it as well.

Who was rendered in/visible? As Kelly tells her story of her early experience with Beverley, Austin and their father, and then retells her story awake to assumptions and beliefs she was not conscious of at the time, she is struck by the fact she cannot find a picture of Austin in her photo album and she cannot remember the father's name. "... while I remember many details of this family, I cannot recall the name of the father. That in itself speaks volumes." These absences speak to Kelly in her present-day space and understandings. She sees now how Austin and his father were distanced from school-marginalized_given no place, or no comfortable place, on the landscape. She understands now how Austin's father's expressed anger was his attempt to be rendered visible as a knower and a decision maker in regard to his son's schooling.

Who was in/validated? In Kelly's story, we feel the emotion experienced by both Kelly and the father in their interchanges regarding Austin. "While not necessarily expecting appreciation over the phone call home, I did expect he would hear me and offer some support in dealing with his child..... I recall my incredulous reaction that he felt I could be to blame for his son's behavior." When Kelly was not appreciated or supported by the father in her judgments of Austin's behavior and, in fact, was blamed by him for setting Austin off, she felt invalidated in her role as teacher and as a holder of professional knowledge. Feeling unsafe, she called on the school principal to be present in her interchanges with the father and to stand with her, validating her perceptions and actions in regard to Austin. Given that Kelly tells us Austin was suspended from school many times that year, it appears she was validated through the support of her principal.

Austin's father, too, felt the emotion of their interchanges. "Our strained communication became increasingly hostile as the year went on." Also feeling blamed, feeling judged as a person and as a parent, not having his opinions listened to, not being given the opportunity to have his knowledge of his child considered, Austin's father was invalidated. Unlike Kelly, he had no where else to go for support and validation. The power and position of the principal, the power inherent in the structure and hierarchy, only served to invalidate him further. Just as Austin's many suspensions over the course of that school year speak to Kelly's validation, they speak to the father's continued invalidation. 
Who finds schooling an educative process-and who does not? Through Kelly's story, it appears Kelly, Austin and Austin's father all learned something about power and position through their interchanges. Kelly, centered on the school landscape, experienced the privileging afforded by power and position. Austin and his father, living in the margins of that landscape, experienced the silencing imposed by those in positions of power. Kelly believes,"The message I gave, the one [the father] clearly received, was I knew best. He had no voice." While Kelly accepts responsibility for her message, the message that educator knows best was also the message communicated by the principal, and the message inherently communicated by the hierarchical structure of the institution. Austin's and his father's experiences with the school, as a result, were mis-educative (Dewey, 1938), teaching them to anticipate that in their experiences with educators they, as family members, would be voiceless and powerless on school landscapes.

It is years later, as Kelly retells her story of Beverley, Austin, and their father, that this experience truly becomes an educative one for her. Awakening to the unconscious assumptions and beliefs at play for her then, Kelly recognizes that the family's milieu and the place of the father as a holder of knowledge about his children, their teaching and their learning was not something she saw as relevant in her former practice. Kelly's living, telling and retelling of her stories of Austin's and Beverley's father challenge her to relive those stories in present time in new ways. Her stories challenge all of us to ask new questions and to see new possibilities as we thoughtfully and deliberately break in on a dominant plotline in which parents and families are overlooked and marginalized in their children's schooling.

\section{Living New Stories in Relation With Parents}

\section{Meeting Beverley's and Austin's Family}

Let's imagine that in her graduate class Kelly had the opportunity to move backward in time to restory her experiences with Beverley, Austin and their father. How might Kelly have chosen to relive her stories with this family? Perhaps when Beverley became a student in Kelly's class, Kelly would have made a call home to Beverley's dad to introduce herself, and to chat with him about his family. Maybe she would have proposed having a coffee together after school as a way to get to know them better-at school, at a local coffee shop, at their home-perhaps including Austin's teacher as well. Maybe she would have invited him to write her a note, telling her important things about Beverley as an individual and a learner and what he 
hoped for her that year. Maybe, given Beverley's interest in journaling, she would have asked Beverley to write about herself and her hopes and dreams, sharing her entry with her father before bringing it to Kelly at school.

With genuine interest expressed in knowing Beverley and her family, with celebratory calls, notes, and visits to the father about Beverley's contributions and accomplishments, with continued and varied invitations to the father to take part in his daughter's schooling, how might Kelly have come to know this father and his children over their time together? Would her story of him still have been a deficit story-an alcoholic who was unemployed, angry and explosive, a man deserted by the mother of his small children-a story told by others? Would her story of him instead have been a story of strength-someone working hard to love and care for his children in very difficult and complex circumstances-a story she came to know on her own?

How might Kelly's relationship with Beverley and her father, and her understanding of their family, have positioned her differently with Austin in her grade 7/8 combined class and differently in her interactions with his father when she wanted to talk with him about Austin's anger and defiance? Perhaps their strained and hostile interactions may have become a conversation.

\section{Imagined Parent/Teacher Conversation}

Kelly: Thanks so much for coming in. I'm trying to get to know Austin, to understand his anger, and to know how to respond to it. When he loses his temper, I just don't know what to do. What I have been doing isn't working. I need your help. I wonder if together we can figure this out.

(Austin's father is given time to respond, to share his knowing of Austin.)

Kelly: (Responding to what the father has shared with her, she asks more questions.) Can you tell me about Austin at home? Does he get angry there too? What kinds of things seem to set him off?

(Austin's father is given time to respond, to share his knowing of Austin.)

Kelly: What do you do then? As a teacher, I've learned that with some kids, when I respond directly and firmly, their pushing stops. I've learned with other kids, though, when I am direct like that, they rise to the challenge and just push back harder. I need to come to them more gently-perhaps with humor, or by giving them space or time, by stepping in quietly and privately. I'm just not sure with 
Austin.

(Austin's father is given time to respond, to share his knowing of Austin.)

Kelly: I know that suspending Austin isn't working. I realize it just makes the problem yours and that isn't helping any of us. What else do you think I might do?

(Austin's father is given time to respond, to share his knowing of Austin.)

Kelly: A school / visited one time had an elders' program. When a child was having a tough time, that child was invited to go and spend time with the elder. The child could just go and have a cup of tea and a visit, like at a grandparent's, or play a game of cards or a board game with the elder. Is there an adult in the school Austin likes and respects that he might like to spend that kind of time with? (Together, Austin's father and Kelly discuss a number of possibilities.)

Kelly: I really want Austin to come to trust me. I know that will take time. Do you think I might spend some time with Austin outside of school every now and then-maybe going for lunch or an after school snack, maybe doing something like going bowling with him and a friend? How do you feel about that? What kinds of things do you think he'd like to do?

(They make a plan, both for response to Austin's anger and for building more trust with him, a plan they both feel committed to. They leave their conversation, having learned from each other's knowledge and experience with Austin, and feeling supported in their roles as parent and teacher.)

\section{Attending to a Curriculum of Family}

Kelly's storying and restorying helps us to see how the curriculum commonplaces are typically lived in a way that privileges teacher knowledge and establishes the school as "the site of the 'main game"' (Cairney \& Munsie, 1992, p. 1) in children's education. It also helps us to see the inherent "superordination/subordination" (Schwab, 1973, p. 509) within the commonplaces, particularly in relation to milieus existing off the school landscape. As curriculum makers, what do we need to do to situate parents in a place of equal rank within the curricular commonplaces? As curriculum makers, how do we attend to children, teaching, and learning in the context of parents and of family and community milieus just as we do in school and classroom milieus? 


\section{Using Parent Knowledge Alongside Teacher Knowledge}

Because Kelly's telling and retelling of her early career experience with Austin's father shares only her story-how she knew and understood the father, his children, their schooling, their lives at that point in time-we are not privy to what knowledge Austin's father may have also held and used in those moments. We can only wonder. What knowledge might he have held as a result of his lived experiences? What knowledge might he have garnered from single parenting his children in the intimate and complex environment of their home and their shared lives?

In the restorying of Kelly's interactions with Austin's father, she recognizes him as a knower, as someone who brings both experience with and insight into Austin's patterns of behavior. She sits alongside him as someone who also holds knowledge of children and their behaviors. While their knowledge is different, arising from varied contexts and varied experiences, Kelly and Austin's father are both positioned to talk and listen, to teach and learn, to lead and follow, to give and take. One knower or one way of knowing does not pre-empt the other. The chances they each will leave their interchange feeling affirmed and supported in their roles are greatly enhanced.

\section{Family and Community as Places of Learning for Educators}

An important point of attention, as we work to create new stories of parents on school landscapes, is how we honor children's lives as they are lived in the context of the families and communities that surround them. When children come to us in schools they are already living multiple identities as grand/daughters or grand/sons, sisters or brothers, nephews or nieces; as orphaned, detained or wards of the system; as situated in neighborhoods, Reserves, on the streets or in other geographical places; as members of racial, cultural, religious, economic groups; and as members of other chosen communities. When they come to school, they come in this multiplicity and contextuality, not independent of it. In both direct and indirect ways, they bring their families and communities with them. Our challenge as educators is to learn to share space in classrooms and schools with all those who accompany them. 
Children's education begins when they are born and is already well underway when they come to school. Schooling adds just one more element to their education. While educators have goals and outcomes for children, mandated by departments of education, reflective of principles of child development, representative of their own philosophical stance, so do parents and family members have hopes and dreams for their children and their education. What might Austin's father have wanted for his son? How might the school have helped Austin move toward his or his father's educational goals?

In new stories of school, we can invite children to bring their lives and their families to school, to tell stories of their families and to hear stories of ours, and to work toward their families' and communities' goals of education as well as our more specific goals of schooling. New stories can move us away from a narrow focus on children's academic achievement to a broad and holistic focus on children's growth and well-being. They can move us away from a stance that isolates us as educators within the walls of the school to one that invites us to move out and attend to lives and learning as "nested" (Lyons, 1990)_nested in families and communities, nested in contexts of food and housing security, labor and employment, adult literacy, the arts, culture, sports and recreation-nested in ways that both shape and are shaped by what we do in schools. New stories can invite us to ask, "How do we make the most significant contribution to children?"

\section{Some Closing Thoughts}

The restorying of Kelly's interactions with Austin's father begins, in small ways, to reflect the benefits for him which may arise out of his interactions with Kelly. The opportunity to share what he knows about Austin, about how best to respond to Austin's anger, to have a voice in and to influence decisions being made at school about responses to Austin's outbursts all honor his right to have power and autonomy in decisions which have large impact for him and his family. As time goes on and their relationship strengthens, how might more attention be paid to what the father and the family may need or want from their engagement with the school? Perhaps Austin's father will want to spend time with Kelly in the classroom, or with the mentor they put in place for Austin, to observe and learn from their interactions with him. Perhaps as a single parent he will want to have coffee occasionally with Kelly or other school personnel who know Austin so he has someone to talk to about his joys, frustrations and the things he is trying to figure out as a parent. Perhaps he 
will want to use a school computer or come in and read the school newspaper as he pursues his search for employment. Perhaps he will want to spend time in the school where he does not have to be alone or is in a safe space away from the pull of his addictions. Perhaps he will want to share with students a hobby or craft he has. Perhaps he will want to take an adult upgrading class offered in the school, get help with completing some forms, seek connections to other human services.... Kelly and the other educators will only know his purposes if they build a trusting relationship with him, if they truly listen-and if they ask him.

In the restorying, we see the benefits of attending to the agendas, the needs and wants, of parents and families at the same time we attend to the agenda of the school. Kelly is stronger because she now has the support of Austin's father and she is learning from what he knows. Austin's father is stronger because he is being listened to, asked for input, learning from Kelly, and being honored as a human being with worth. Austin and Beverley are stronger because there is less anger in their lives and more unified attention being paid to their success and well-being, in school and outside of it. The restorying reflects what I believe was Schwab's (1973) conceptualization of the four curricular commonplaces as being equal in rank and coordinated. Each "vital factor" (p. 509) is attended to when the work of teachers and schools is done relationally and situated in the midst of families and communities. Children, parents and families, educators and schools are all strengthened in this new plotline.

With Kelly's telling and retelling of her story, we challenged ourselves to consider what opportunities are missed, and what harm may be done, when educators continue to live out a dominant plotline in their stories of parents. We challenged ourselves to consider who is rendered in/visible, who is in/validated, who finds schooling an educative process - and who is/does not. I believe we have responsibility to ask ourselves these same questions about the curriculum of teacher education, both preservice and inservice. What opportunities are missed, and what harm may be done, when we do not develop and implement a teacher education curriculum that invites educators to tell, and then to retell and relive their stories of parents in ways that create relational and socially just educational experiences? Without a teacher education curriculum that attends as equally to milieus, particularly those of family and community, as it does to the other commonplaces, who will continue to be rendered in/visible in our schools, who will continue to be in/validated, and for whom will schooling be a mis/educative process? 


\section{Notes}

1. See, as examples, the work of Clandinin and Connelly, Clark, Cochran-Smith, and Lytle, Hollingsworth, Loughran, Russell, and Schulman.

2. In February 2009, Elise Hoey, an undergraduate research assistant, searched the Web sites of Faculties of Education in representative universities across Canada (University of British Columbia, University of Alberta, University of Saskatchewan, University of Manitoba, Ontario Institute for Studies in Education [OISE]/ University of Toronto, McGill University, University of New Brunswick, St. Francis Xavier University, University of Prince Edward Island, and Memorial University) to determine what courses developed around the topic of working with parents are being offered in undergraduate and graduate programs.

3. See, for example, EADM 425 Legal and Institutional Contexts of Education (University of Saskatchewan, 2008-2009) or ED 5062 Cultural Constructions of Childhood (University of New Brunswick, 2008-2009).

\section{References}

Cairney, T.H., \& Munsie, L. (1992). Beyond tokenism: Parents as partners in literacy. Victoria, Australia: Shortrun Books.

Craig. C.J. (2003). Narrative inquiries of school reform: Stories lives, storied landscapes, storied metaphors. Grenwich, CT: Information Age Publishing.

Dewey, J. (1938). Experience and education. New York: Collier/Macmillan.

Henderson, A.T., \& Mapp, K.L. (2002). A new wave of evidence: The impact of school, family, and community connections on student achievement. Austin, TX: Southwest Educational Development Laboratory (National Center for Family \& Community Connections with Schools). Retrieved November 4, 2005, from http://www.sedl. org/connectins/resources/evidence.pdf.

Hoover-Dempsey, K.V., Walker, J.M.T., Sandler, H.M., Whetsel, D., Green, C.L., Wilkins, A.S., et al. (2005, November). Why do parents become involved? Research findings and implications. The Elementary School Journal, 106(2), 105-131.

Jeynes, W.H. (2005, May). A meta-analysis of the relation of parental involvement to urban elementary school student academic achievement. Urban Education, (40)3, 237-269.

Lacey, K. (2007). Walking in good company: A reflective journey of programming for early adolescent learners. Unpublished master's project, University of Saskatchewan, Saskatoon, Saskatchewan.

Loomba, A. (1998). Colonialism/Postcolonialism. London: Routledge.

Lyons, N. (1990). Dilemmas of knowing: Ethical and epistemological dimensions of teachers' work and development. Harvard Educational Review, 60(2), 159-180. 
Pushor, D., \& Stelmach, B. (2007). EADM 892 Parents and education: Contemporary developments and issues course syllabus. University of Saskatchewan, Saskatoon, Saskatchewan.

Redding, S., Langdon, J., Meyer, J., \& Sheley, P. (2004). The effects of comprehensive parent engagement on student learning outcomes. Cambridge, MA: Family Involvement Network of Educators (Harvard Family Research Project). Retrieved May 9, 2009, from http://www. hfrp.org/publications-resources/browseour-publications/the-effects-of-comprehensive-parent-engagement-on-studentlearning-outcomes.

Schwab, J.J. (1973, August). The practical 3: Translation into curriculum. The School Review, 81(4), 501-522.
University of New Brunswick. (n.d.). University of New Brunswick undergraduate calendar 2008-2009. Retrieved February 11, 2009, from http://eservices.unb.ca/calendar /undergraduate/display_desc.cgi?numbe $r=E D \% 25205062$.

University of Saskatchewan. (n.d.) University of Saskatchewan Course Calendar 20082009. Retrieved March 1, 2009, from http://www.usask.ca/calendar/coursecat/.

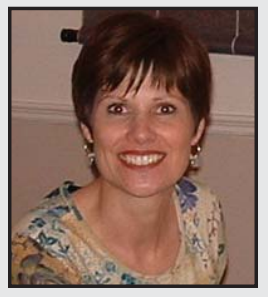

Debbie Pushor is an Associate Professor in the Department of Curriculum Studies at the University of Saskatchewan. Debbie's program of research includes narrative inquiries into "parent knowledge" and "parent engagement." In her teaching, Debbie makes central an often absent conversation in teacher education about the positioning of parents in schooling.

\section{LINKTO:}

http://www.debbiepushor.com 